\title{
UM ANO DEPOIS, FICA A \\ PERGUNTA: QUEM PAGOU A CONTA \\ DOS PROTESTOS DE JUNHO?
}

Coluna publicada em 1.7.2014:<http://www.conjur.com.br/2014-jul-01/ contas-vista-ano-depois-quem-pagou-conta-protestos-junho $>$

Não, não me refiro às vidraças quebradas e outros vandalismos. Estou falando de outra conta. Uma conta que parece não fechar.

Completou-se um ano desde que todo o país se viu contaminado por uma onda de protestos que, se todos se recordam, iniciou-se por manifestações insurgindo-se contra o aumento de 20 centavos na passagem de ônibus urbano em São Paulo. E que depois incluíram reclamações contra o aumento dos pedágios, gastos com a Copa do Mundo, corrupção e um sem-número de outras reivindicações, como melhorias na saúde, educação e tantas outras.

O fato é que boa parte das reivindicações surtiram efeito. Os ônibus urbanos e o metrô em São Paulo não tiveram suas passagens aumentadas, nem os pedágios. Aumentos que, à época, eram considerados "essenciais" para manter o equilíbrio orçamentário, dos contratos com os parceiros privados e a ordem nas contas públicas, tanto no governo municipal quanto no estadual em São Paulo, e o mesmo ocorreu nas demais unidades da federação também atingidas pela onda de protestos.

À época, o prefeito Fernando Haddad "estimou em 175 milhões de reais o gasto adicional até o fim do ano com o congelamento da tarifa em 3 reais (em vez de 3,20 reais). Até 2016, esse custo extra chegará em 2,7 bilhōes de reais". Informou ainda que esse custo "significaria deixar de construir 200 mil casas populares ou abrir mão de $10 \%$ do investimento previsto para o mandato". Para o Estado de São Paulo, do governador Geraldo Alckmin, o congelamento dos bilhetes de metrô e trem representaria "uma perda anual de receita de 210 milhões de reais", valor com o qual "seria possível construir 30 escolas técnicas ou 30 ambulatórios no interior”. No Rio de Janeiro, em que os ônibus tiveram redução de R \$ 2,95 para 
$\mathrm{R} \$ 2,75$, estimou-se um "rombo de até 500 milhões de reais no orçamento da prefeitura”, valor próximo ao que se gastaria para a manutenção de 70 clínicas. ${ }^{1}$

Pois um ano já se passou, as passagens continuam com o mesmo valor e, aparentemente, nada de mais grave aconteceu com as contas públicas.

Mas não é só.

No final do ano passado, o prefeito de São Paulo propôs novos valores para o IPTU, justificando-o como fundamental para o equilíbrio nas contas, até em razão do suposto "rombo" causado pelo alegado aumento nas despesas com o subsídio das passagens de ônibus. Com o reajuste suspenso em razão de decisão judicial, as receitas extras não vieram.

A questão que se coloca é: deixaram de ser construídas as 200 mil casas populares em São Paulo? Houve redução de 10\% dos investimentos públicos? Os paulistas ficaram sem as 30 escolas técnicas ou ambulatórios? O Rio de Janeiro deixou de manter 70 clínicas?

Até o momento não se veem explicações plausíveis, convincentes e, principalmente, claras sobre esse ajuste nas contas públicas. Afinal, como essa conta foi paga? Quem pagou?

Questões que deveriam ter a resposta expressa nos orçamentos públicos e respectivos relatórios e balanços. Mas não parece ser o caso.

As leis orçamentárias definem as receitas e despesas públicas dos entes da federação todos os anos, estabelecendo e definindo o que vai ser feito com o dinheiro público, delineando os exatos valores a serem gastos em cada uma das ações governamentais - razões suficientes para tornar essas leis as mais importantes do ordenamento jurídico depois da Constituição. ${ }^{2}$

Os orçamentos públicos surgiram inicialmente como instrumentos voltados ao controle das finanças públicas, evoluíram para assumir importantes funções na gestão do setor público, sendo atualmente fundamentais também para o planejamento governamental.

Para cumprir aquela que sempre foi e continua sendo uma função essencial desta lei tão importante, qual seja, a de controle das finanças e, consequentemente, de toda a atuação governamental, os orçamentos públicos devem ser peças dotadas de clareza e transparência, permitindo que sejam compreensíveis e capazes de

\footnotetext{
1 Revista Veja, versão digital, edição histórica, n. 2.327, ano 46, n. 26, de 26 de junho de 2013, reportagem especial "Os sete dias que mudaram o Brasil - A conta é para todos", p. 3.

2 Min. Carlos Ayres Britto, ADI-MC 4.048-1/DF, j. 14.5.2008, p. 92 dos autos.
} 
revelar com exatidão as atividades financeiras do Estado, a fim de que todos possam saber o que se fez, o que se faz e o que se fará com o dinheiro público. Somente assim será possível, não apenas aos órgãos encarregados da fiscalização financeira e orçamentária, mas também e principalmente à sociedade, exercer o controle sobre a atividade financeira do Estado.

A transparência passa a assumir uma importância que a torna hoje um dos mais - se não o mais - relevantes princípios orçamentários, e a ela tem sido dada cada vez mais atenção.

A Lei de Responsabilidade Fiscal, em seus artigos 48 a 49, ao tratar da transparência na gestão fiscal, exige que se dê ampla divulgação às leis orçamentárias, prestações de contas e relatórios fiscais, por todos os meios, para que se amplie o acesso público a essas informaçooes, além de incentivar a participação popular na elaboração das leis orçamentárias.

A observância dessas e de outras normas é essencial para que se tenha uma efetiva participação popular e controle social sobre a atividade financeira do Estado, que está expressa nas leis orçamentárias, responsáveis por traduzir, nas descriçôes dos programas e respectivas dotaçôes, o que a sociedade deseja fazer com os recursos que entrega para o poder público. $\mathrm{O}$ ordenamento jurídico brasileiro, hoje, reflete um novo padrão de gestão da coisa pública, caracterizado pela participação popular e responsabilização dos administradores, na busca de uma administração pública cada vez mais transparente e responsável. ${ }^{3}$

Ao decidir o que fazer com o dinheiro público - sempre escasso para a administração que precisa dele para cumprir suas funções e, invariavelmente, excessivo para os contribuintes que devem pagar seus tributos e tarifas -, escolhas hão de ser feitas, afinal os recursos não permitem atender a tudo e a todos. No mais das vezes, "escolhas trágicas", como já se fez referência em outras colunas publicadas neste mesmo espaço. ${ }^{4}$

Os ônibus podem até ser "grátis", como pretenderam os manifestantes em junho de 2013. Tudo depende de decisóes que cabe à sociedade tomar e ao poder público atender, alocando os recursos orçamentários da forma desejada pela sociedade, tendo-se em consideração que essa gratuidade é ilusória e alguém pagará essa conta. ${ }^{5}$

3 ASSONI FILHO, Sérgio. Transparência fiscal e democracia. Porto Alegre: Núria Fabris, 2009, p. 171.

4 No fundo, protestos envolvem questôes orçamentárias, publicada em 2 de julho de 2013, e Passe livre no transporte depende de reserva do possivel, publicada em 16 de julho de 2013, além de outras.

5 CARVALHO, André C. Direito da infraestrutura: perspectiva pública, São Paulo: Quartier Latin, 2014, p. 318. 
Ou seja, trata-se, substancialmente, de definir quem financia o que e como. Em outras palavras: a sociedade como um todo pagando impostos ou os usuários pagando tarifas.

Para se tomar uma decisão e fazer escolhas, é imprescindível ter informação sobre as opções. Saber as consequências. Permitir que se avaliem os custos e benefícios. E isso só é possível com transparência nas contas públicas. É, pois, fundamental que os orçamentos públicos sejam dotados da mais absoluta transparência, sem o quê as escolhas deixam de ser democráticas e fragilizam-se a fiscalização das contas públicas e o controle social das atividades governamentais. E transparência não se resume a tornar públicas as informaçôes. É preciso que sejam compreensíveis e úteis. ${ }^{6}$

É evidente que os orçamentos públicos são leis que estampam peças complexas de contabilidade pública, até porque não é possível haver simplicidade na discriminação de despesas da ordem de $\mathrm{R}$ \$ 2,5 trilhões, como é o caso do orçamento da Uniāo para este exercício financeiro de 2014.

Mas deveriam ser suficientemente claros para permitir que se respondam às questóes colocadas desde o início deste texto. Afinal, quando se decidiu por não aumentar uma série de tarifas, escolhas foram feitas. É importante saber quais foram elas, quem as fez e quais as consequências dessas escolhas.

Será que os recursos que faltaram vieram de melhorias na gestão, o que já não era sem tempo, pois há muito se sabe que o dinheiro público pode ser mais bem utilizado? ${ }^{7}$

Ou não. Podem ter sido tirados recursos de outras áreas tão ou mais importantes do que o transporte coletivo. Nesse caso, quais teriam sido? A população está de acordo com isso? Foi consultada? Participou de alguma forma dessa decisão? Quem tomou a decisão? Foram os governantes? Ou foram burocratas que realocaram recursos sem que ninguém saiba de onde saíram?

São muitas as perguntas. A transparência na gestão fiscal mostra, cada vez mais, sua relevância. Mostra também que é um princípio incipiente já começou a produzir resultados, mas está longe do ideal. Há ainda um longo caminho a percorrer.

Todos nós aguardamos as respostas.

6 RUBINSTEIN, Flávio. Notas sobre a transparência fiscal no Direito Financeiro. In CONTI, José Mauricio e SCAFF, Fernando F. (coords.). Orçamentos públicos e direito financeiro. São Paulo: RT, 2011, p. 905.

7 Vide coluna Não falta dinheiro à administração pública, falta gestão, publicada em 31 de julho de 2012. 